\title{
Effectiveness of Injectable Ibuprofen Salts and Indomethacin to Treat Patent Ductus Arteriosus in Preterm Infants: Observational Cohort Study
}

\author{
Deonne Dersch-Mills, Belal Alshaikh, Amuchou S Soraisham, Albert Akierman, and Kamran Yusuf
}

\begin{abstract}
Background: There is no injectable ibuprofen product marketed to treat patent ductus arteriosus (PDA) in newborns in Canada. The authors' institution has used ibuprofen arginine in the past. In the absence of published evidence supporting use of this salt form of ibuprofen for neonatal PDA, a retrospective analysis was undertaken.
\end{abstract}

Objective: To compare the effectiveness and adverse effects of ibuprofen arginine, ibuprofen tromethamine, and indomethacin in the treatment of PDA.

Methods: This retrospective observational cohort study, for patients admitted between 2009 and 2015, included preterm infants with symptomatic PDA who received at least one dose of injectable indomethacin, ibuprofen tromethamine, or ibuprofen arginine. Three effectiveness end points were analyzed: closure after one course of treatment, repeat medical treatment, and surgical ligation. The secondary end points included acute kidney injury, necrotizing enterocolitis, chronic lung disease, and time to full enteral feeding.

Results: A total of 179 infants were included. There were no differences among groups in terms of closure after one course of treatment (37/54 [69\%] with indomethacin, 42/70 [60\%] with ibuprofen tromethamine, and $28 / 55$ [51\%] with ibuprofen arginine; $p=0.21$ ) or surgical ligation (10/54 [19\%] with indomethacin, 13/70 [19\%] with ibuprofen tromethamine, and $12 / 55$ [22\%] with ibuprofen arginine; $p=0.88$ ). However, there was a difference regarding use of a repeat course of treatment, ibuprofen arginine having the highest rate (8/54 [15\%] with indomethacin, 18/70 [26\%] with ibuprofen tromethamine, and 20/55 [36\%] with ibuprofen arginine; $p=0.04)$. After adjustment for gestational age, the association between ibuprofen arginine and increased use of a repeat course of treatment remained significant. The groups did not differ with respect to adverse effects.

Conclusion: These results highlight the potential for differences in effectiveness among various salt forms of injectable ibuprofen and indomethacin. Because of the small sample size and retrospective methodology, confirmation of the present results through a larger prospective study is needed.

\section{RÉSUMÉ}

Contexte : Il n'y a pas sur le marché de produit injectable à base d'ibuprofene pour traiter la persistance du canal artériel (PCA) chez le nouveau-né au Canada. Libuprofene arginine a été utilisé auparavant dans l'établissement de santé des auteurs. En l'absence de données publiées appuyant l'utilisation de ce médicament sous forme de ce sel pour traiter la PCA chez le nouveau-né, une analyse rétrospective a été réalisée.

Objectif : Comparer l'efficacité et les effets indésirables de l'ibuprofene arginine, de l'ibuprofene trométhamine et de l'indométhacine dans le traitement de la PCA.

Méthodes : Cette étude de cohorte observationnelle rétrospective, au sujet de patients hospitalisés entre 2009 et 2015, incluait des nourrissons prématurés atteints d'une PCA symptomatique ayant reçu par injection au moins une dose d'indométhacine, d'ibuprofene trométhamine ou d'ibuprofene arginine. Trois paramètres d'évaluation de l'efficacité ont été analysés : la fermeture après un seul traitement, la répétition du traitement médical et la ligature chirurgicale. Les paramètres d'évaluation secondaires étaient les cas d'insuffisance rénale aiguë, d'entérocolite nécrosante et de maladie pulmonaire chronique ainsi que le temps pour atteindre l'alimentation entérale complète.

Résultats : Au total, 179 nourrissons ont été admis à l'étude. Aucune différence n'a été relevée entre les groupes en ce qui touche à la fermeture après un seul traitement (37/54 [69\%] pour l'indométhacine, 42/70 [60 \%] pour l'ibuprofene trométhamine et 28/55 [51 \%] pour l'ibuprofene arginine; $p=0,21)$ ou à la ligature chirurgicale (10/54 [19\%] pour l'indométhacine, 13/70 [19\%] pour l'ibuprofene trométhamine et $12 / 55$ [22\%] pour l'ibuprofene arginine; $p=0,88$ ). Cependant, une différence a été observée pour ce qui est de la répétition du traitement et l'ibuprofene arginine a obtenu le taux le plus élevé (8/54 [15\%] pour l'indométhacine, 18/70 [26\%] pour l'ibuprofene trométhamine et 20/55 [36\%] pour l'ibuprofene arginine; $p=0,04)$. Après ajustement pour l'âge gestationnel, l'association entre l'utilisation de l'ibuprofene arginine et une augmentation du recours à un second traitement demeurait significative. Il n'y avait pas de différence entre les groupes en ce qui touche aux effets indésirables. 
Keywords: ductus arteriosus, patent; infant, newborn; indomethacin; ibuprofen; ibuprofen arginine

\section{Can J Hosp Pharm. 2018;71(1):22-8}

Conclusion : Ces résultats soulignent la possible différence d'efficacité parmi les divers sels d'ibuprofene injectable et l'indométhacine. Cependant, en raison de la petite taille de l'échantillon et de l'emploi d'une méthodologie rétrospective, une étude prospective plus importante doit être menée pour confirmer les résultats de la présente étude.

Mots clés : persistance du canal artériel, nouveau-né, nourrisson, indométhacine, ibuprofene, ibuprofene arginine

\section{INTRODUCTION}

$\mathrm{A}$ bout $55 \%$ of infants born with body weight less than $1000 \mathrm{~g}$ have a symptomatic patent ductus arteriosus (PDA) requiring medical treatment. ${ }^{1,2} \mathrm{~A}$ persistent $\mathrm{PDA}$ can lead to undesirable pulmonary, renal, and gastrointestinal (GI) effects, thus warranting medical or surgical treatment. ${ }^{3-9}$ A 2010 meta-analysis reported that ibuprofen was as effective as indomethacin in closing a PDA and reduced the risk of necrotizing enterocolitis (odds ratio [OR] 0.68) and renal insufficiency (OR 0.28 for urine output declining to $<1 \mathrm{~mL} / \mathrm{kg}$ per hour) relative to indomethacin. ${ }^{10}$

Until early 2010, indomethacin was the sole treatment option for PDA at the Foothills Medical Centre, a 39-bed level 3 neonatal intensive care unit (NICU) in Calgary, Alberta. At that time, a shortage of indomethacin led to use of injectable ibuprofen, which is available in various salt forms. Starting in 2010, ibuprofen tromethamine was obtained through Health Canada's Special Access Programme and was used for PDA treatment in the unit. From 2011 to 2013, both indomethacin and ibuprofen tromethamine were available and used for this purpose. In 2013, ibuprofen arginine came onto the Canadian market; given its apparently more reliable availability and lower cost, it was adopted as first-line treatment for symptomatic PDA. Of note, the salt form used in most initial ibuprofen efficacy trials has been ibuprofen lysine, which is available in the United States and Europe. ${ }^{11-16}$ Although many studies do not indicate the salt form of injectable ibuprofen used, ibuprofen tromethamine ${ }^{17,18}$ and ibuprofen arginine ${ }^{19}$ have also been studied.

Although the efficacy and safety of ibuprofen for treatment of PDA in neonates has been well described, published data on use of the arginine salt of this drug are limited to a single abstract. ${ }^{19}$ A difference in pharmacological activity between salt forms is not expected, given that salts of the various ibuprofen products deliver similar amounts of ibuprofen (amount of ibuprofen in $10 \mathrm{mg}$ of salt forms: lysine, $0.028 \mathrm{mmol}$; tromethamine, $0.030 \mathrm{mmol}$; arginine, $0.026 \mathrm{mmol})$. However, data on the use of ibuprofen tromethamine has indicated higher rates of necrotizing enterocol- itis relative to placebo, and 3 cases of pulmonary hypertension have been reported. ${ }^{17}$ These adverse effects are postulated to be related to the timing of administration of ibuprofen tromethamine $(<6 \mathrm{~h}$ from birth) or to an effect of the tromethamine buffer. ${ }^{10}$ Arginine is a precursor of nitric oxide $(\mathrm{NO})$, and ibuprofen arginine has been shown to release $\mathrm{NO}$ in animal models. ${ }^{20}$ The role of NO in ductal patency has been demonstrated in animal models, and use of an NO synthase inhibitor in combination with indomethacin was associated with improved ductal closure rates in premature newborns relative to indomethacin alone. ${ }^{21-24}$ These data provide a theoretical reason to doubt the effectiveness of ibuprofen arginine for PDA. In addition, a previous study that compared the effectiveness of ibuprofen arginine and indomethacin in preterm neonates demonstrated that ibuprofen arginine had a significantly lower closure rate after one course ( $37 \%$ versus $65 \%, p=0.006)$ and a higher PDA ligation rate $(15 \%$ versus $2 \%, p=0.03) .{ }^{19}$ For these reasons, an audit of the effectiveness of ibuprofen arginine for treatment of PDA was deemed prudent.

The objective of this study was to compare the effectiveness of ibuprofen arginine with that of indomethacin and ibuprofen tromethamine in terms of the following outcomes:

- closure of the PDA during initial course of medical therapy;

- failure of initial course of medical therapy, necessitating a repeat course of medical therapy;

- failure of medical treatment, necessitating surgical ligation of the PDA.

The secondary objectives were to compare the incidence of adverse effects of PDA treatment (GI bleeding, spontaneous intestinal perforation, acute kidney injury) and the incidence of necrotizing enterocolitis and chronic lung disease among the 3 groups.

\section{METHODS}

This retrospective, observational cohort study included all infants at the Foothills Medical Centre NICU with gestational 
age less than 32 weeks and/or birth weight less than $1500 \mathrm{~g}$ who had symptomatic PDA requiring pharmacological intervention and received at least one dose of a study drug during the following 3 periods: March 2009 to February 2010 (the indomethacin cohort), March 2010 to February 2011 (the ibuprofen tromethamine cohort), and June 2013 to January 2015 (the ibuprofen arginine cohort). Infants with ductal dependent heart disease, major congenital anomalies, or a contraindication to ibuprofen or indomethacin (urine output $<1 \mathrm{~mL} / \mathrm{h}$ in the preceding $12 \mathrm{~h}$, serum creatinine $>120 \mu \mathrm{mol} / \mathrm{L}$, platelet count $<60 \times 10^{\%} / \mathrm{L}$, presence of necrotizing enterocolitis, or active bleeding) were excluded. Waiver of consent and the full protocol were approved by the University of Calgary Conjoint Health Research Ethics Board.

The computerized order entry system was used to identify infants who received ibuprofen or indomethacin during the 3 study periods. Medical records were reviewed for relevant data. Patients were followed until death or discharge from the NICU.

The decision to treat a PDA was based on clinical signs and symptoms, supplemented by echocardiography confirmation of a hemodynamically significant PDA. Indomethacin (Indocid P.D.A., Merck Frosst Canada) was given in 3 doses (if $<48 \mathrm{~h}$ of life, doses of $0.2,0.1$, and $0.1 \mathrm{mg} / \mathrm{kg}$; if 2-7 days of life, doses of $0.2,0.2$, and $0.2 \mathrm{mg} / \mathrm{kg}$; and if $>7$ days of life, doses of $0.2,0.25$, and $0.25 \mathrm{mg} / \mathrm{kg}$ ) at $12-\mathrm{h}$ intervals. Ibuprofen tromethamine (Pedea, Orphan Europe SARL) was given in 3 doses (10, 5, and $5 \mathrm{mg} / \mathrm{kg}$, respectively) at 24-h intervals. Data from these 2 groups of patients had been collected previously and formed the historical comparator groups for this study. ${ }^{18}$ Ibuprofen arginine (Caldolor, Alveda Pharmaceuticals) was used at the same dosage as ibuprofen tromethamine.

All infants receiving these agents were monitored clinically and biochemically to look for ductal closure and possible medication-related side effects. In cases of persistent hemodynamically significant PDA (as documented by echocardiography), a repeat course of either agent was used unless contraindicated. Surgical ligation of PDA was considered for those with failure of 2 courses of pharmacological therapy and those with contraindications to the medications.

The primary outcome was effectiveness of treatment, as defined by the following criteria:

- closure of the PDA during the initial course of medical therapy (as confirmed by echocardiography or determined by clinical resolution of symptoms);

- failure of initial course of medical therapy, necessitating a repeat course;

- failure of treatment, necessitating surgical ligation of the PDA.

The following secondary end points were also assessed:

- GI bleeding;

- spontaneous intestinal perforation;

- necrotizing enterocolitis stage II or greater (based on modified Bells staging $)^{25}$;
- acute kidney injury (urine output $<0.5 \mathrm{~mL} / \mathrm{kg}$ per hour for more than $8 \mathrm{~h}$ or increase in serum creatinine $>30 \mu \mathrm{mol} / \mathrm{L}$ within $72 \mathrm{~h}$ of medication administration or $\geq 50 \%$ from baseline) ${ }^{26}$;

- diagnosis of chronic lung disease (oxygen requirement at 36 weeks corrected gestational age);

- age (days of life) when full enteral feeding was achieved.

Descriptive statistics (means and proportions) were used to describe the 3 study groups. Categorical variables were compared among the groups using the $\chi^{2}$ test or the Fisher exact test, with a priori significance level of 0.05 . Continuous variables were compared using analysis of variance. Patients with missing data were excluded from analysis for the applicable variable; hence, the sample size was reduced for some end points. To account for differences in baseline characteristics and other confounding factors, multivariable logistic regression was used to determine the influence of covariates on the study end points. Factors that differed among groups at a significance level of $p<0.1$ in the bivariate analysis and those with a known association with PDA were considered for inclusion in the model.

\section{RESULTS}

The ibuprofen arginine cohort had lower mean birth weight $(p=0.001)$ and appeared to be more acutely ill than the other cohorts, with lower 5-minute APGAR scores $(p=0.012)$, higher SNAP-II scores (Score for Neonatal Acute Physiology) $(p<0.001$ ), and a higher rate of antenatal steroid use $(p=0.008)$ (Table 1).

There were no significant differences among the groups in terms of complete or clinical PDA closure after one course of treatment $(p=0.21)$ and need for PDA ligation $(p=0.88)$ (Table 2 ). However, there was a difference in terms of need for a repeat course of medical treatment, the ibuprofen arginine group having a significantly higher rate than the other groups $(p=0.04)$. A post hoc analysis was performed on the proportion of patients who received both a repeat course of treatment and ligation surgery, but there was no significant difference among the groups $(p=0.34)$.

There did not appear to be any differences among the groups in terms of incidence of acute kidney injury; however, for this variable there was a high proportion of missing data for the ibuprofen arginine cohort (Table 2). Similarly, no differences were seen regarding incidence of necrotizing enterocolitis, chronic lung disease, time to achieve full enteral feeding, or death before NICU discharge. Because of low event rates, statistical analysis was not performed for the incidence of GI bleeding $(n=2$ in indomethacin group, $n=4$ in ibuprofen tromethamine group, $n=0$ in ibuprofen arginine group) or intestinal perforation ( $n=0$ in indomethacin group, $n=1$ in ibuprofen tromethamine group, $n=4$ in ibuprofen arginine group). 
Table 1. Characteristics of Patients and Their Mothers by Treatment Group

\begin{tabular}{|c|c|c|c|c|}
\hline \multirow[b]{2}{*}{ Characteristic } & \multicolumn{3}{|c|}{ Treatment Group; No. (\%) of Patients* } & \multirow[b]{2}{*}{$p$ Valuet } \\
\hline & $\begin{array}{l}\text { Indomethacin } \\
\quad(n=54)\end{array}$ & $\begin{array}{c}\text { Ibuprofen } \\
\text { Tromethamine } \\
(n=70)\end{array}$ & $\begin{array}{c}\text { Ibuprofen } \\
\text { Arginine } \\
(n=55)\end{array}$ & \\
\hline $\begin{array}{l}\text { Gestational age (weeks) } \\
(\text { mean } \pm \text { SD) }\end{array}$ & $26.9 \pm 2.3$ & $26.6 \pm 2.1$ & $26.2 \pm 1.8$ & 0.24 \\
\hline Birth weight $(g)($ mean \pm SD) & $1004 \pm 272$ & $992 \pm 347$ & $811 \pm 22 \neq$ & 0.001 \\
\hline Sex, male & $27(50)$ & $44(63)$ & $30(55)$ & 0.34 \\
\hline Multiple gestations & $20(37)$ & $25(36)$ & $17(31)$ & 0.77 \\
\hline Prenatal steroids & $46(85)$ & $55(79)$ & 54 (98) §ף & 0.008 \\
\hline Chorioamnionitis & $19(35)$ & $16(23)$ & $9(16)$ & 0.07 \\
\hline Cesarean section & $30(56)$ & $38(54)$ & $39(71)$ & 0.13 \\
\hline $\begin{array}{l}\text { APGAR score at } 5 \text { min } \\
\text { (median and IQR) }\end{array}$ & $7(7-8)$ & $7(7-8)$ & $6(5-7)^{\star *+\dagger}$ & 0.012 \\
\hline SNAP-\|ll score (mean \pm SD) & $15.6 \pm 13.0$ & $14.1 \pm 7.8$ & $23.8 \pm 17.1 \neq \neq$ & $<0.001$ \\
\hline $\mathrm{IVH} \geq$ grade III & $7(13)$ & $7(10)$ & $12(22)$ & 0.16 \\
\hline \multicolumn{5}{|c|}{ 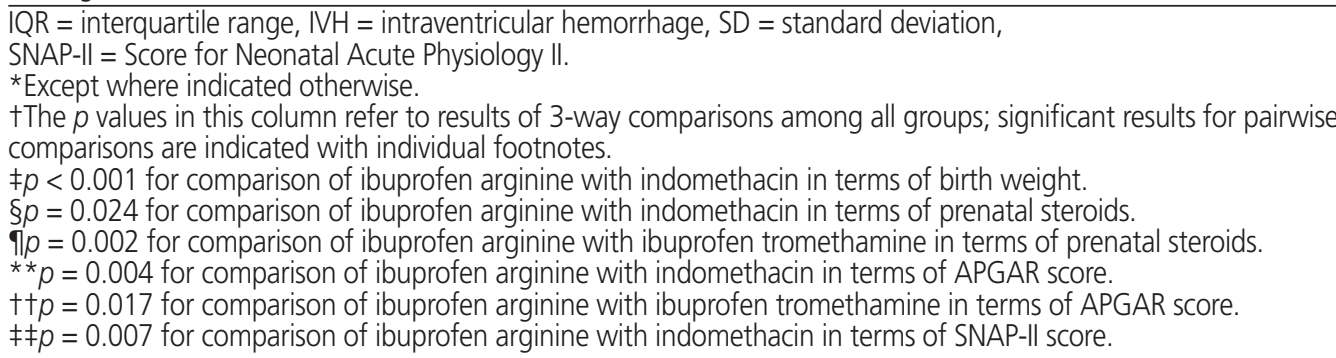 } \\
\hline
\end{tabular}

Logistic regression was performed on the 3 components of the primary end point. Factors that differed among groups at a significance level of $p<0.1$ in the bivariate analysis (birth weight, antenatal steroids, APGAR score, SNAP-II score, age [days of life] at start of treatment) and the factor with a known association with PDA (chorioamnionitis) ${ }^{27}$ were considered for inclusion in the model. Gestational age was substituted for birth weight because of collinearity of these 2 factors and because external factors have less influence on gestational age than on birth weight. APGAR score was not included because of collinearity with SNAP-II score. After adjustment, only gestational age showed a significant association with complete or clinical closure and with the need for surgical ligation. Use of ibuprofen arginine showed a significant association with repeat course of PDA treatment (Table 3).

\section{DISCUSSION}

In this retrospective analysis, the agent used for PDA treatment did not appear to affect the rate of clinical or complete closure after the initial course of treatment or the need for surgical ligation, which was reassuring. However, use of ibuprofen arginine appeared to be associated with greater use of repeat treatment courses. Given the similar quantity of ibuprofen delivered from its various salts, and meta-analytic data supporting similar efficacy between other ibuprofen salts and indomethacin, ${ }^{10}$ this result was unexpected.

Potential explanations for this unexpected finding include the release of NO by ibuprofen arginine. ${ }^{20}$ Although release of NO could theoretically reduce the effectiveness of ibuprofen arginine in PDA treatment, the amount of arginine provided through therapeutic doses of this agent is very low $(0.024$ $\mathrm{mmol} / \mathrm{kg}$ daily; dose for prevention of necrotizing enterocolitis $1.5 \mathrm{mmol} / \mathrm{kg}$ daily). ${ }^{28}$ It is possible that this is the explanation for the increased need for repeat courses of treatment, and that this study was too small to show differences in the other effectiveness end points. The closure rate was numerically lower with ibuprofen arginine (51\%) than with indomethacin (69\%) and ibuprofen tromethamine $(60 \%)$, although the comparison did not reach statistical significance.

A more likely explanation is that these findings represent biases in practice. Given the study's retrospective and uncontrolled design, there was no standard decision-making model for initiation of medical treatment for PDA or for repetition of the course of treatment. The greater use of repeat courses of treatment with ibuprofen arginine could reflect increased clinician comfort with ibuprofen over indomethacin because of its more favourable safety profile. ${ }^{10}$ The ibuprofen arginine cohort was the most recent cohort, and comfort with ibuprofen's safety profile may have been building over time. Greater use of repeat medical treatment with ibuprofen arginine could also represent growing skepticism toward ibuprofen's efficacy among neonatologists, which is supported by subjective observations at our centre. This skepticism may have influenced clinicians' decisions about whether or not an infant would benefit from a repeated course of treatment.

The results for closure and ligation rates reported here differ from those reported in the only other study examining use of ibuprofen arginine for PDA in preterm neonates. ${ }^{19}$ That study 
Table 2. Outcomes by Treatment Group

\begin{tabular}{|c|c|c|c|c|}
\hline \multirow[b]{2}{*}{ Characteristic } & \multicolumn{3}{|c|}{ Treatment Group; No. (\%) of Patients* } & \multirow[b]{2}{*}{$p$ Valuet } \\
\hline & $\begin{array}{l}\text { Indomethacin } \\
\quad(n=54)\end{array}$ & $\begin{array}{c}\text { Ibuprofen } \\
\text { Tromethamine } \\
(n=70)\end{array}$ & $\begin{array}{c}\text { Ibuprofen } \\
\text { Arginine } \\
(n=55)\end{array}$ & \\
\hline $\begin{array}{l}\text { Age at start of treatment } \\
\text { (days of life) (mean } \pm \text { SD) }\end{array}$ & $3.7 \pm 2.5$ & $5.5 \pm 4.6 \neq$ & $5.6 \pm 5.2 \S$ & 0.04 \\
\hline \multicolumn{5}{|l|}{ First course of treatment } \\
\hline Completed & $36(67)$ & $62(89) \uparrow$ & $45(82)$ & 0.01 \\
\hline Not completed & $18(33)$ & $8(11)$ & $10(18)$ & \\
\hline \multicolumn{5}{|l|}{ Reason for non-completion } \\
\hline Renal & $9(50)$ & $2(25)$ & $3(30)$ & \\
\hline Gastrointestinal & $1(6)$ & $2(25)$ & 0 & \\
\hline Bleeding & $2(11)$ & $1(13)$ & 0 & \\
\hline Closure before completion & $6(33)$ & $3(37)$ & $6(60)$ & \\
\hline Unknown & 0 & 0 & $1(10)$ & \\
\hline \multicolumn{5}{|l|}{ Primary end point } \\
\hline $\begin{array}{l}\text { Complete or clinical closure } \\
\text { after first course of treatnment }\end{array}$ & $37(69)$ & $42(60)$ & $28(51)$ & 0.21 \\
\hline $\begin{array}{l}\text { Received repeat course } \\
\text { of treatment }\end{array}$ & $8(15)$ & $18(26)$ & $20(36)^{\star *}$ & 0.04 \\
\hline Underwent surgical ligation & $10(19)$ & $13(19)$ & $12(22)$ & 0.88 \\
\hline $\begin{array}{l}\text { Received both repeat course } \\
\text { of treatment and surgical ligation }\end{array}$ & $4(7)$ & $8(11)$ & $9(16)$ & 0.34 \\
\hline \multicolumn{5}{|l|}{ Secondary end points } \\
\hline Acute kidney injury & $11(20)$ & $10 / 69(14)$ & $2 / 10(10)$ & 0.49 \\
\hline $\begin{array}{l}\text { Necrotizing enterocolitis } \\
\geq \text { stage II }\end{array}$ & $5(9)$ & $5(7)$ & $8(15)$ & 0.38 \\
\hline Chronic lung disease & $27 / 46(59)$ & $38 / 68(56)$ & $23 / 42(55)$ & 0.93 \\
\hline $\begin{array}{l}\text { Age at full enteral feeding } \\
\text { (days of life) (mean } \pm \text { SD) }\end{array}$ & $23.9 \pm 11$ & $24.3 \pm 10$ & $27.4 \pm 16$ & 0.28 \\
\hline Death before NICU discharge & $2(4)$ & $3(4)$ & $4(7)$ & 0.65 \\
\hline \multicolumn{5}{|c|}{$\begin{array}{l}\mathrm{NICU}=\text { neonatal intensive care unit, SD = standard deviation. } \\
\text { *Except where indicated otherwise. Where data were missing for some patients, both numerator and denominator } \\
\text { are shown. } \\
\text { †The } p \text { values in this column refer to results of 3-way comparisons among all groups; significant results for pairwise } \\
\text { comparisons are indicated with individual footnotes. } \\
\neq p=0.013 \text { for comparison of ibuprofen tromethamine with indomethacin in terms of age at start of treatment. } \\
\S p=0.022 \text { for comparison of ibuprofen arginine with indomethacin in terms of age at start of treatment. } \\
\text { १p } p=0.003 \text { for comparison of ibuprofen tromethamine with indomethacin in terms of completion of first course of } \\
\text { treatment. } \\
{ }_{* \star}^{*} p=0.01 \text { for comparison of ibuprofen arginine with indomethacin in terms of repeat course of treatment. }\end{array}$} \\
\hline
\end{tabular}

Table 3. Results of Regression Analysis (Relative to Indomethacin Control)

\begin{tabular}{|c|c|c|}
\hline \multirow[b]{2}{*}{ End Point } & \multicolumn{2}{|c|}{ Comparison Group; Adjusted OR* $(95 \% \mathrm{Cl})$} \\
\hline & Ibuprofen Tromethamine & Ibuprofen Arginine \\
\hline $\begin{array}{l}\text { Closure after first course } \\
\text { of treatment }\end{array}$ & $0.75(0.33-1.71)$ & $0.60(0.25-1.47)$ \\
\hline $\begin{array}{l}\text { Received repeat course } \\
\text { of treatment }\end{array}$ & $1.74(0.60-5.02)$ & $4.25(1.34-13.4)$ \\
\hline Underwent surgical ligation & $0.73(0.25-2.16)$ & $1.00(0.31-3.20)$ \\
\hline
\end{tabular}

( $n=86$ patients) reported that patients treated with ibuprofen arginine had significantly lower closure rates after one course of treatment $(37 \%$ with ibuprofen arginine versus $65 \%$ with indomethacin, $p=0.006)$ and a higher PDA ligation rate $(15 \%$ with ibuprofen arginine versus $2 \%$ with indomethacin, $p=0.03) .{ }^{19}$ The differences observed here were much smaller (for closure, 51\% with ibuprofen arginine versus 69\% with indomethacin, $p=0.21$; for ligation, $22 \%$ with ibuprofen arginine versus $19 \%$ with indomethacin, $p=0.88$ ). These differences could reflect differences in selection of patients for medical treatment 
and surgical referral, which would be supported by the significantly higher rates of ligation in our cohort. Further support for this theory is difficult to ascertain because the results of the previous study were published in abstract form only. ${ }^{19}$

Failure rates in both of the current ibuprofen cohorts were higher than what was reported in the meta-analysis ( $40 \%$ with ibuprofen tromethamine and $49 \%$ with ibuprofen arginine in the current study versus about $26 \%$ in the meta-analysis ${ }^{10}$ ). The lower rate reported previously could be related to patient selection, although there has also been some discussion in the literature about the need for higher ibuprofen doses, starting in 2005. ${ }^{29}$ More recently, in 2012, Dani and others ${ }^{30}$ reported improved rates of PDA closure with an ibuprofen dosing regimen of 20,10, and $10 \mathrm{mg} / \mathrm{kg}$ given at 24-h intervals, with no increase in adverse effects. Use of this higher-dose regimen might improve closure rates seen at our centre, but would need to be evaluated before widespread adoption.

As reported in the meta-analysis, ${ }^{10}$ the rates of acute kidney injury, chronic lung disease, necrotizing enterocolitis, and death in the present cohorts did not differ among treatment groups. However, the current study was likely too small to detect differences in these end points, and missing data because of inconsistent measurement of serum creatinine further reduced the sample size for acute kidney injury. There were no statistically significant differences in rate of necrotizing enterocolitis, although the rate was numerically higher in the ibuprofen arginine group (15\% versus $9 \%$ with indomethacin and $7 \%$ with ibuprofen tromethamine, $p=0.38$ ). There was also no difference among cohorts in the time needed to reach full enteral feeding, but again this was numerically (if not statistically) higher in the ibuprofen arginine group (27.4 days versus 23.9 with indomethacin and 24.3 days with ibuprofen tromethamine, $p=0.28$ ). These observations may be due to the younger gestational age and lower birth weight of the ibuprofen arginine group at baseline. The incidence of GI bleeding and intestinal perforation were too low to analyze, and further examination of these outcomes in a larger study may be warranted.

During the periods of ibuprofen tromethamine and indomethacin use that were analyzed in this study, these were the only PDA treatment options available on the units. However, during the period when ibuprofen arginine was used, indomethacin was also available, and oral ibuprofen had become a more frequently used agent for PDA treatment. This difference in clinical context has the potential to confound our end points, as clinician bias may have played a role in selection of the initial agent, as well as the agent used for repeat courses of treatment. For example, 2 patients in the ibuprofen arginine group received indomethacin for their repeat course, and 1 patient in this group received oral ibuprofen.

To our knowledge, this study is the first to compare multiple salts of ibuprofen and indomethacin in terms of the end points of PDA treatment in neonates; however, it was limited by its retrospective observational design. The higher rate of repeat treatment courses with ibuprofen arginine could represent clinician bias in deciding when to use repeat courses, either because of comfort with ibuprofen's safety or skepticism about ibuprofen's effectiveness. The sample sizes were limited by the timelines for availability of the 3 agents, and the study was therefore too small to show differences in rates of the less common end points (i.e., adverse effects). Overall, confirmation of the present results through a larger prospective study would be ideal. The results would further inform Canadian neonatal clinicians' ability to use a more readily accessible injectable ibuprofen product, rather than one available only through Health Canada's Special Access Programme.

\section{CONCLUSION}

Ibuprofen arginine has been more accessible and less expensive than other PDA treatment options at the authors' centre, but the potential for differing effectiveness (based on the theoretical effects of $\mathrm{NO}$ and data presented only in abstract form) required that its use be audited before widespread adoption. Other salts of ibuprofen have been shown to have effects similar to those of indomethacin, with evidence of lower rates of necrotizing enterocolitis and renal dysfunction. Our data suggest similar closure rates after one course and similar surgical ligation rates, but an increased need for repeat courses of PDA treatment with ibuprofen arginine. This difference may represent clinician bias in initiating and repeating courses of medical treatment with ibuprofen that have developed over time. No significant differences were observed among the 3 treatments regarding adverse effects. The effectiveness of ibuprofen arginine should be examined in larger cohorts with appropriate randomization and controls.

\section{References}

1. Koch J, Hensley G, Roy L, Brown S, Ramaciotti C, Rosenfeld CR. Prevalence of spontaneous closure of the ductus arteriosus in neonates at a birth weight of 1000 grams or less. Pediatrics. 2006;117(4):1113-21.

2. Clyman RI. Ibuprofen and patent ductus arteriosus. $N$ Engl J Med. 2000;343(10):728-30

3. Scholl JE, Yanowitz TD. Pulmonary hemorrhage in very low birth weight infants: a case-control analysis. J Pediatr. 2015;166(4):1083-4.

4. Cotton RB, Stahlman MT, Kovar I, Catterton WZ. Medical management of small preterm infants with symptomatic patent ductus arteriosus. J Pediatr. 1978;92(3):467-73.

5. Mullaart RA, Hopman JC, Rotteveel JJ, Stoelinga GBA, De Haan AFJ, Daniëls $\mathrm{O}$. Cerebral blood flow velocity and pulsation in neonatal respiratory distress syndrome and periventricular hemorrhage. Pediatr Neurol. 1997; 16(2):118-25.

6. Dollberg S, Lusky A, Reichman B. Patent ductus arteriosus, indomethacin and necrotizing enterocolitis in very low birth weight infants: a populationbased study. J Pediatric Gastroenterol Nutr. 2005;40(2):184-8.

7. Schena F, Francescato G, Cappelleri A, Picciolli I, Mayer A, Mosca F, et al. Association between hemodynamically significant patent ductus arteriosus and bronchopulmonary dysplasia. J Pediatr. 2015;166(6):1488-92. 
8. Noori S, McCoy M, Friedlich P, Bright B, Gottipati V, Seri I, et al. Failure of ductus arteriosus closure is associated with increased mortality in preterm infants. Pediatrics. 2009;123(1):e138-44.

9. Hamrick SEG, Hansmann G. Patent ductus arteriosus of the preterm infant. Pediatrics. 2010;125(5):1020-30.

10. Ohlsson A, Walia R, Shah SS. Ibuprofen for the treatment of patent ductus arteriosus in preterm and/or low birth weight infants. Cochrane Database Syst Rev. 2010;(4):CD003481.pub4.

11. Van Overmeire B, Smets K, Lecoutere D, Van de Broek H, Weyler J, De Groote K, et al. A comparison of ibuprofen and indomethacin for closure of patent ductus arteriosus. N Engl J Med. 2000;343(10):674-81.

12. Hammerman C, Shchors I, Jacobson S, Schimmel MS, Bromiker R, Kaplan $\mathrm{M}$, et al . Ibuprofen versus continuous indomethacin in premature neonates with patent ductus arteriosus: is the difference in the mode of administration? Pediatr Res. 2008;64(3):291-7.

13. Lago P, Bettiol T, Salvadori S, Pitassi I, Vianello A, Chiandetti L, et al. Safety and efficacy of ibuprofen versus indomethacin in perterm infants treated for patent ductus arteriosus: a randomized controlled trial. Eur J Pediatr. 2002;161(4):202-7.

14. Mosca F, Bray M, Lattanzio M, Fumagalli M, Tosetto C. Comparative evaluation of the effects of indomethacin and ibuprofen on cerebral perfusion and oxygentation in preterm infants with patent ductus arteriosus. J Pediatr. 1997;131(4):549-54.

15. Su PH, Chen JY, Su CM, Huang TZ, Lee HS. Comparison of ibuprofen and indomethacin therapy for patent ductus arteriosus in preterm infants. Pediatr Int. 2003;45(6):665-70.

16. Van Overmeire B, Follens I, Hartmann S, Creten WL, Van Acker KJ. Treatment of patent ductus arteriosus with ibuprofen. Arch Dis Child Fetal Neonatal Ed. 1997;76(3):F179-84.

17. Gournay V, Roze JC, Kuster A, Daoud P, Cambonie G, Hascoet JM, et al. Prophylactic ibuprofen versus placebo in very premature infants: a randomised, double-blind, placebo-controlled trial. Lancet. 2004; 364(9449):1939-44.

18. Sivanandan S, Bali V, Soraisham AS, Harabor A, Kamaluddeen M. Effectiveness and safety of indomethacin versus ibuprofen for the treatment of patent ductus arteriosus in preterm infants. Am J Perinatol. 2013;30(9): 745-50.

19. Rogerson S, Thornley C, Schmoelzer G, Fox LM. Ibuprofen is less effective than indomethacin for closure of haemodynamically significant patent ductus arteriosus after 72 hours [abstract]. Combined 17th Congress of the Federation of Asian and Oceania Perinatal Societies and 16th Annual Congress of the Perinatal Society of Australia and New Zealand; 2012 Mar; Sydney, Australia. J Paediatr Child Health. 2012;48 Suppl S1:44-5.

20. De Palma C, Di Paola R, Perrotta C, Mazzon E, Cattaneo D, Trabucchi E, et al. Iburpofen-arginine generates nitric-oxide and has enhanced antiinflammatory effects. Pharmacol Res. 2009;60(4):221-8.

21. Momma K, Toyono M. The role of nitric oxide in dilating the fetal ductus arteriosus in rats. Pediatr Res. 1999;46(3):311-5.

22. Richard C, Gao J, LaFleur B, Christman BW, Anderson J, Brown N, et al. Patency of the preterm fetal ductus arteriosus is regulated by endothelial nitric oxide synthase and is independent of vasa vasorum in the mouse. Am J Physiol Regul Integr Comp Physiol. 2004;287(3):R652-60.

23. Reese J, O'Mara PW, Poole SD, Brown N, Tolentino C, Eckman DM, et al. Regulation of the fetal mouse ductus arteriosus is dependent on interaction of nitric oxide and COX enzymes in the ductal wall. Prostaglandins Other Lipid Mediat. 2009;88(3-4):89-96.
24. Kellar RL, Tacy TA, Fields S, Ofenstein JP, Aranda JV, Clyman RI. Combined treatment with a nonselective nitric oxide synthase inhibitor (L-NMMA) and indomethacin increases ductus constriction in extremely premature newborns. Pediatric Res. 2005;58(6):1216-21.

25. Walsh MC, Kliegman RM. Necrotizing enterocolitis: treatment based on staging criteria. Pediatr Clin North Am. 1986;33(1):179-201.

26. Duzova A, Bakkaloglu A, Kalyoncu M, Poyrazoglu H, Delibas A, Ozkaya O, et al.; Turkish Society for Pediatric Nephrology Acute Kidney Injury Study Group. Etiology and outcome of acute kidney injury in children. Pediatr Nephrol. 2010;25(8):1453-61.

27. Park HW, Choi YS, Kim KS, Kim SN. Chorioamnionitis and patent ductus arteriosus: a systematic review and meta-analysis. PLoS One. 2015;10(9): e0138114.

28. Arginine hydrochloride [monograph]. In: Lexicomp Online [database]. Hudson (OH): Lexi-Comp; [cited 2016 Nov 12]. Available from: http:// online.lexi.com/lco/action/home. Subscription required to access content.

29. Desfrere L, Zohar S, Morville P, Brunhes A, Chevret S, Pons G, et al. Dose-finding study of ibuprofen in patent ductus arteriosus using the continual reassessment method. J Clin Pharm Ther. 2005;30(2):121-32.

30. Dani C, Vangi V, Bertini G, Pratesi S, Lori I, Favelli F, et al. High-dose ibuprofen for patent ductus arteriosus in extremely preterm infants: a randomized controlled study. Clin Pharmacol Ther. 2012;91(4):590-6.

Deonne Dersch-Mills, BScPharm, ACPR, PharmD, is with the Inpatient Pharmacy, Alberta Children's Hospital (Alberta Health Services), Calgary, Alberta.

Belal Alshaikh, MD, is with the Section of Neonatology, Department of Pediatrics, University of Calgary, Calgary, Alberta.

Amuchou S Soraisham, MD, is with the Section of Neonatology, Department of Pediatrics, University of Calgary, Calgary, Alberta.

Albert Akierman, MD, is with the Section of Neonatology, Department of Pediatrics, University of Calgary, Calgary, Alberta.

Kamran Yusuf, MD, is with the Section of Neonatology, Department of Pediatrics, University of Calgary, Calgary, Alberta.

Competing interests: None declared.

Address correspondence to:

Dr Deonne Dersch-Mills

Inpatient Pharmacy

Alberta Children's Hospital

2888 Shaganappi Trail NW

Calgary AB T3B 6A8

e-mail: deonne.dersch-mills@ahs.ca

Funding: This study was funded internally by Alberta Health Services Pharmacy Department. There was no external funding or support.

Acknowledgement: The authors wish to thank Jayesh Changela for his work on data collection for this project. 